\title{
Pendidik Yang Membelajarkan (Gaya Bank vs Hadap Masalah)
}

\author{
Samsul Bahri \\ Fakultas Tarbiyah dan IImu Keguruan IAIN Kendari \\ Jl. Sultan Qaimuddin, No. 17 Baruga Kendari, Sulawesi Tenggara Indonesia \\ E-mail: samsulbahri1@gmail.com
}

\begin{abstract}
This paper proves that the fundamental problem in teaching is the instructor who uses a bank style teaching model that casts off the potential of student creativity which leads to authoritarian feudalistic teaching in which students such as tabula rasa, blank white paper must be filled, therefore the facts empirically, the battle between the two models of teaching is still very much dominated by the teaching model in the style of the bank. By that, the writing of giving agat solutions to teaching models to problems is the choice of the instructors because this model is able to build participants' creativity and democratization in learning. With this model education can develop a humanizing mission for human beings, or students and able to produce generations that are of good quality in a scientific way, as well as morals seem to be realized.
\end{abstract}

Keywords: Educator, Bank Style, Problem Solve.

\begin{abstract}
Abstrak
Penelitian ini membuktikan bahwa problem mendasar dalam pengajaran yakni pengajar yang menggunakan model pengajaran ala gaya bank yang mengebiri potensi kreativitas peserta didik yang membawa ke arah pengajaran feodalistik otoriter di mana peserta didik seperti tabula rasa, kerta putih kosong yang harus di isi, oleh karena itu fakta empiriknya, pertarungan kedua model pengajaran ini, masih sangat didominasi oleh model pengajaran ala gaya bank. Olehnya itu, tulisan memberikan solusi agat model pengajaran hadap masalah menjadi pilihan para pengajar karena model ini mampu membangun kreativitas peserta dan demokratisasi dalam pembelajaran. Dengan model tersebut pendidikan dapat mengembang misi memanusiakan manusia, atau peserta didik serta mampu mencetak generasi-generasi yang berkualitas baik secara keilmuan, maupun moral tampak dapat terwujud.
\end{abstract}

Kata Kunci: Pendidik, Membelajarkan, Gaya Bank, Hadap masalah. 


\section{Pendahuluan}

Potret pendidikan yang sejatinya mengembang misi memanusiakan manusia, atau peserta didik yang dapat mencetak generasi-generasi yang berkualitas baik secara keilmuan, maupun moral tampaknya belum mampu terwujud. Kini telah telah digantikan dengan berbagai persoalan, mulai dari maraknya tawuran antar pelajar ataupun antar mahasiswa, kekerasan di sekolah, profesionalisme guru, kasus mencontek massal dan sebagainya adalah bagian dari benang kusut dunia pendidikan yang menjadi perhatian bersama.

Multi persoalan di atas, menurut KH. Abdullah Syukri Zarkasyi karena pendidikan seharusnya tidak hanya menekankan pengajaran pada aspek kognitif, tetapi juga bagaimana membangun sifat mental serta watak anak didik. ${ }^{1}$ Atau aspek afektif dan psikomotorik menjadi titik sentral bagi guru dalam mendesain pembelajaran yang membelajarkan peserta didik. Hal ini diakui oleh Muchtar Buchori dalam bukunya Praktek Pendidikan dalam Renungan, yang mengatakan banyak guru yang hanya mengajar tetapi tidak mendidik sehingga tidak pernah berhasil dalam membelajarkan peserta didik ${ }^{2}$ bahkan ironisnya guru hanya pamer ilmu pengetahuan di depan peserta didik, sehingga menjadi guru yang ditakuti dan disegani, tidak untuk kritik di dalam kelas karena akan berakibat pada nilai, dalam konteks inilah peserta didik terbenam dalam kebudayaan bisu (the culture of silence), Oleh karena itu, teori pendidikan gaya bank yang dikumandankan Paulo Freire menjadi kenyataan bahwa dunia pendidikan senantiasa memperlihatkan hubungan harmonis yang melibatkan tiga unsur yakni pengajar, anak didik, dan realitas dunia. Hubungan ketiga obyek tersebut disadari atau tidak sadari (cognizable), tidak terdapat pada pendidikan yang selama ini telah mapan. Karena itu, sistem pendidikan menurut Paulo Freire diandaikan sebuah bank (bangking concept of education) di mana pelajar diberi pengetahuan agar ia kelak dapat mendatangkan hasil dengan lipat ganda. Jadi anak didik adalah obyek investasi dan sumber deposito potensial. ${ }^{3}$

Model pengajaran seperti inilah yang tidak membelajarkan peserta didik. Filosofi pendidikan Paulo Freire merupakan sumber inspirasi para fasilitator pembelajaran yang menggunakan idiom partisipasi, pemberdayaan, dan pembebasan.

Penelitian ini membahas Model pengajar yang membelajarkan dengan menggunakan sumber yang otoritatif.

\footnotetext{
${ }^{1}$ Lihat Republika 10 April, 5

${ }^{2}$ Muchtar Buchori, Ilmu Pendidikan dan Praktek Pendidikan, 30.

${ }^{3}$ Paulo Freire, Politik Pendidikan, Kebudayaan, Kekuasaan, dan Pembebasan, x.
} 


\section{Metode Penelitian}

Penelitian ini merupakan penelitian kualitatif dengan kategori penelitian kepustakaan (library research), yang terdiri dari mencatat semua temuan mengenai Konsep gaya pendidik secara umum pada setiap pembahasan penelitian yang didapatkan dalam literatur-literatur dan sumber-sumber, dan atau penemuan terbaru mengenai gaya pendidik dalam pembelajaran. Setelah mencatat, kedua, memadukan segala temuan, baik teori atau temuan baru pada Gaya pendidik dalam pembelajaran. Ketiga, menganalisis segala temuan dari berbagai bacaan, berkaitan dengan kekurangan tiap sumber, kelebihan atau hubungan masing-masing tentang wacana yang dibahas di dalamnya. Terakhir adalah mengkritisi, memberikan gagasan kritis dalam hasil penelitian terhadap wacana-wacana sebelumnya dengan menghadirkan temuan baru dalam mengolaborasi pemikiran-pemikiran yang berbeda.

Pengumpulan data dalam penelitian ini dimulai dari identifikasi wacana dari buku-buku, makalah atau artikel, majalah, jurnal, web (internet), ataupun informasi lainnya yang berhubungan dengan judul penulisan untuk mencari hal-hal atau variabel yang berupa catatan, transkrip, buku, surat kabar, majalah dan sebagainya yang berkaitan dengan kajian tentang model gaya belajar gaya bank dan hadap masalah.

Analis data dalam penelitian ini dimulai dari Pertama, analisis pada saat pengumpulan data, ini ditujukan untuk lebih menangkap esensi atau inti dari fokus penelitian yang akan dilakukan melalui sumber-sumber yang dikumpulkan dan terkandung dalam rumusan verbal kebahasaan, proses ini dilakukan aspek demi aspek, sesuai dengan peta penelitian. Kedua, setelah dilakukan proses pengumpulan data itu, selanjutnya menganalisis kembali setelah data terkumpul yang berupa data mentah yang harus ditentukan hubungan satu sama lain.

\section{Pengajaran Model Gaya Bank}

Dalam paradigma pembelajaran, Membelajarkan, adalah upaya pendidik untuk membantu 'peserta didik' melakukan kegiatan belajar. Membelajarkan merupakan kegiatan sistematis dan dilakukan secara sengaja oleh pendidik untuk membantu peserta didik agar melakukan kegiatan belajar. Oleh karena itu, konteks mengajar menjadi kata kunci yang sangat mempengaruhi keberhasilan sebuah proses pendidikan, hal disebabkan adanya intraksi komunikasi antara pendidik dan anak didik. Namun demikian, fakta empriknya banyak intraksi komunikasi yang dilakukan pendidik dianggap gagal membelajarkan anak didiknya. Fakta inilah yang kemudian mendapat kritikan para pemikir pendidikan seperti Muhammad Abduh (18491905) yang menilai bahwa metode pengajaran yang digunakan para guru adalah salah. Ia antara lain menilai bahwa metode pengajaran yang digunakan 
para guru adalah salah. Guru lebih menekankan pada metode hafalan. Abduh secara tegas mengeritik pengajaran di al-azhar Mesir. ${ }^{4}$ Sejalan dengan hal tersebut, Abu Hasan al-Amiri (w.381H/992M) juga menekankan untuk tidak mengadakan dikotomi pembelajaran ilmu-ilmu hasil pemikiran dan ilmu-ilmu keagamaan. ${ }^{5}$

Kritikan di atas, merupakan problem pembelajaran yang tidak pernah membelajarkan peserta didik. Atau dengan kata lain model pembelajaran pasif, yakni guru menerangkan, murid mendengar, guru mendiktekan, murid mencatat, guru bertanya, murid menjawab dan seterusnya. ${ }^{6}$ Bahkan peserta didik lebih banyak diminta menghafal teks baku dibandingkan mengembangkan pemikiran kreatif. Sehingga dalam jangka panjang, akan mengakibatkan disiplin ilmu rasional menjadi tidak berkembang di dunia Islam, yang akhirnya mempengaruhi pemikiran Islam secara keseluruhan pun terhambat karena tidak ada tantangan serta dorongan. ${ }^{7}$ Hal ini diakui Mohctar Buchori bahwa model pengajaran seperti ini guru terjebak hanya pada perbuatan asyik membeberkan pengetahuan yang dimilikinya dan menikmati kekaguman yang diperlihatkan peserta didiknya atau pamer ilmu pengetahuan. $^{8}$

Dampak dari paradigma pengajaran seperti ini adalah ketakutan dan kebingungan peserta didik pada sang guru, bahkan menurut Abuddin Nata guru besar sejarah dan filsafat pendidikan Islam UIN Syarif Hidayatullah Jakarta menilai bahwa model pengajaran otororiter menempatkan guru menjadi satu-satunya agent of information atau agent of knowledge. Hal ini pada gilirannya membawa konsep pembelajaran yang berpusat pada guru

${ }^{4}$ Diantara kritikan yang dimajukan ketika itu ialah: kurikulum al-Azhar banyak menekankan kepada perberdaan pendapat dari pada mempelajari nilai argumentasinya, perbedaan dari pada arti dan tujuan gramatika bahasa, hukum-hukum fiqih yang timbul dalam saat tertentu dari pada metode penilaian hukum-hukum tersebut untuk dijadikan pedoman. Oleh karena itu Abduh mencari ilmu-ilmu yang disebut oleh Syaikh Darwisy di luar al Azhar. Ilmu-ilmu itu dijumpai pada seorang ulama yang bernama Syaik Hasan Thawil yang mengetahui filsafat, logika, ilmu ukur, soal-soal dunia dan politik. Akan tetapi, Abduh kurang puas dengan pelajaran yang diberikannya. Kepuasan dalam mempelajari filsafat, matematika, teologi dan sebagainya yang ia peroleh dari Jamal al-Din al-Afgani yang datang ke Mesir pada tahun 1870. Suwito, Pendidikan Yang Membebaskan, 2.

${ }^{5}$ Setidaknya ada lima alasan yang dimajukan oleh al-Amiri tentang ini: (1) Wahyu tidak bertentangan dengan pendapat akal, (2) Al-Qur'an mendorong umat Islam untuk mempelajari penciptaan alam, (3) bahwa mempelajari penciptaan alam akan mendapatkan hukum kausalitas, 4) menambah keyakinan, (5) bermanfaat secara nyata bagi kehidupan. Baca Ahamad Abd al-Hamid Ghurab, Abu Hasan al-Amiri wa Ara'uh al-Tarbawiyyah, dalam, Min A'lami al-Tarbiyah al-Tarbiyyah al-Arabiyyah al-Islamiyyah, Jilid II, 96-97.

${ }^{6}$ Dede Rosyada, Paradigma Pendidikan Demokratis, Prenada, .89

7 Suwito, Pendidikan Yang Membebaskan, 23.

${ }^{8}$ Muchtar Buchori, Ilmu Pendidikan dan Praktek Pendidikan, 31 
(teacher centris). ${ }^{9}$ Guru memberikan sejumlah pengetahuan yang harus dihafal dan dikuasai dengan baik oleh peserta didik, tanpa ada peluang bagi peserta didik untuk mempertanyakan urgensitas dan relevansitas yang ajarkan oleh guru. Model pengajaran ini disebut pendidikan ala komando yang dilakukan secara hierarkis, dari atas ke bawah dari guru kepada siswa, ${ }^{10}$ guru adalah komandan dan murid adalah bawahan. Guru akan tersinggung apabilah murid terlalu banyak bertanya atau mempertanyakan perintah dan intruksi yang diberikan guru kepadanya. Metode yang dipakai dalam pola pendidikan semacam ini pastilah metode ceramah. Tugas murid adalah menelan tanpa mengunyah. ${ }^{11}$ Model Pengajaran inilah yang diistilahkan oleh Paul Suparno dalam bukunya Guru Demokratis di Era Reformasi, yakni pengajaran feodalistik otoriter dimana guru terjebak dalam teori filsafat pendidikan klasik yang menempatkan peserta didik dianggap tabula rasa, kertas putih kosong yang harus di isi guru dengan air pengetahuan. ${ }^{12}$ Lebih para lagi pola feodalisme yang cenderung kepada atasan dan bawahan juga seringkali melandasi pola pengajaran kita. Guru berada di kelas dengan jiwa "Father knows best". Guru tahu segalanya dan murid tidak tahu apa. Guru tidak bisa salah dan sebaliknya murid selalu salah. Murid tidak didorong untuk mengembangkan kreativitasnya dengan mengoptimalkan daya imajinasinya dan inovasinya melainkan cukup menghafalkan. Dengan demikian tidak akan pernah menjadi manusia mandiri, tetapi pengekor. ${ }^{13}$

Oleh karena itu, diakui atau tidak model di atas, adalah konsep pendidikan ala gaya bank yang telah dipraktekkan oleh para pendidik dalam proses belajar mengajar, bahkan lebih dari itu, pendidikan gaya bank telah mengakibatkan terjadinya kebekuan berpikir serta tidak munculnya kesadaran kritis pada diri peserta didik. Hal ini dikarenakan pendekatan yang biasa dipakai dalam konsep pendidikan ini adalah pendekatan bercerita (narrative) yang mengarahkan peserta didik untuk menghafal secara mekanis apa isi pelajaran yang diceritakan. Dengan demikian, para peserta didik mempunyai tugas, menghafal apa yang disampaikan oleh guru, dengan kata lain, apa yang disampaikan guru itupulalah yang diceritakan tanpa menyadari dan memahami arti dan makna yang sesungguhnya. Lebih buruk lagi, diubahnya menjadi bejana-bejana kosong untuk diisi oleh guru. Semakin penuh ia mengisi wadah-wadah itu, semakin baik pula seorang guru. ${ }^{14}$ Oleh sebab itu, pendidikan hanya menjadi sebuah kegiatan menabung, di mana para

\footnotetext{
${ }^{9}$ Abuddin Nata, Perspektif Islam tentang Strategi Pembelajaran, h. 149.

${ }^{10}$ Lihat Muska Mosston, Teaching from Command to Dicovery,35

${ }^{11}$ Suwito, Pendidikan Yang Membebaskan,14

${ }^{12}$ Paul Suparno, Guru Demokrasi di Era Reformasi, 29

${ }^{13}$ Suwito, Pendidikan Yang Membebaskan,14

${ }^{14}$ Paulo Freire, Pendidikan Kaum Tertindas, 50.
} 
murid dan guru adalah celengannya dan guru adalah penabungnya, sehingga implikasinya terjadinya dis komunikasi antara guru dan murid, guru menyampaikan pernyataan-pernyataan dan diterima, dihafal dan diulangi dengan patut oleh para murid. Inilah konsep pendidikan gaya bank.

Dalam konsep pendidikan gaya bank, ruang gerak yang disediakan bagi kegiatan murid hanya terbatas pada menerima, mencatat dan menyimpang. Karenanya, pendidikan akhirnya bersifat negatif di mana guru memberi informasi yang harus ditelan oleh murid, yang wajib diingat dan dihapalkan. Secara sederhana Paulo Freire menyusun daftar antagonisme pendidikan gaya bank itu. Menurutnya, ${ }^{15}$ sebagai berikut:

1. Guru mengajar, murid belajar

2. Guru tahu segalanya, murid tidak tahu apa-apa

3. Guru berpikir, murid dipikirkan

4. Guru bicara, murid mendengarkan

5. Guru mengatur, murid diatur

6. Guru memilih dan memaksakan pilihannya, murid menuruti

7. Guru bertindak, murid membayangkan bagaimana bertindak sesuai dengan tindakan gurunya

8. Guru memilih apa yang akan diajarkan, murid menyesuaikan diri

9. Guru mengecaukan wewenang ilmu pengetahuan dengan wewenang profesionalismenya, dan mempertentangkannya dengan kebebasan murid-murid

10. Guru adalah subyek proses belajar, murid obyeknya.

Dari gambaran di atas, dapat terlihat bahwa gurulah yang menjadi pusat segalanya, maka merupakan hal lumrah saja jika murid-murid kemudian mengidentifikasikan diri seperti gurunya sebagai prototip manusia ideal yang harus ditiru dan digugu, harus diteladani dalam semua hal. Karena itu, dalam konsep pendidikan gaya bank, pengetahuan merupakan sebuah anugerah yang dihibahkan oleh mereka yang dianggap tidak memiliki pengetahuan apaapa. Guru menampilkan diri dihadapan murid-muridnya sebagai orang yang berada pada pihak yang berlawanan, dengan mengaggap mereka mutlak bodoh , maka ia mengukuhkan keberadaan dirinya sendiri. Menurut Paulo Freire dengan mengutip dialektika Hegel mengatakan bahwa dalam konsep pendidikan gaya bank para murid bagaikan budak yang terasing, menerima

${ }^{15}$ Paulo Freire, Politik Pendidikan, Kebudayaan, Kekuasaan, dan Pembebasan, xi. 
kebodohan mereka sebagai pengesahan keberadaan sang guru, ${ }^{16}$ sehingga tidaklah mengherankan jika konsep pendidikan gaya bank memandang peserta didik sebagai makhluk yang dapat disamakan dengan sebuah benda dan gampang diatur. Bahkan sangat efektif untuk membekukan kesadaran kritis dan mereduksi keterlibatan dalam mengubah dunia.

Dengan demikian pendidikan gaya bank juga memiliki kemampuan untuk mengurangi atau menghapuskan daya kreasi pada murid serta menumbuhkan sikap muda percaya. Hal ini menguntungkan kaum penindas. Kaum penindas memanfaatkan humanitarianisme mereka untuk melindungi situasi menguntungkan bagi diri mereka sendiri. Oleh karena itu secara naluriah mereka akan selalu menentang setiap usaha percobaan dalam bidang pendidikan yang akan merangsang kemampuan kritis dan tidak puas dengan dengan pandangan terhadap dunia yang berat sebelah, akan tetapi selalu mencari ikatan yang menghubungkan satu hal-hal lainnya atau satu masalah dengan masalah lain. ${ }^{17}$

Dari pemahaman konsep pendidikan gaya bank, nampak jelas bahwa peranan pendidik adalah mengatur cara dunia masuk ke dalam diri para peserta didik. Tugasnya adalah mengatur suatu proses yang berlangsung secara spotan, mengisi para murid dengan menabungkan informasi yang ia anggap sebagai pengetahuan yang sebenarnya. Yang termasuk pendidikan gaya bank adalah anggapan akan adanya dikotomi antara manusia dengan dunia, karena itu manusia adalah penontong bukan pencipta. ${ }^{18}$ Atau dengan kata lain, peserta didik diajar untuk tidak melihat ada hubungan apa yang diajarkan dengan apa yang secara nyata dilakakukan. Dalam pandangan ini, manusia lebih merupakan pemilik sebuah kesadaran; suatu jiwa kosong yang secara pasif terbuka untuk menerima apa saja yang disodorkan oleh realitas dunia luar. Hal ini diakui oleh Roger, bahwa konsep pendidikan bank adalah usaha untuk menjadikan manusia sebagai benda yang terkendali (automaton), bahkan penolakan terhadap fitrah ontologis mereka untuk menjadi manusia seutuhnya. ${ }^{19}$

Pandangan demikian membawa guru dalam anggapan bahwa murid adalah obyek yang tak berkesadaran, senangtiasa pasif dan menerima apa saja yang diberikan oleh guru. Untuk itu, pendidikan yang bergaya bank ini tidak menyadari bahwa tidak ada ketenraman sejati dalam peranannya yang berlebihan dan berusaha hidup bersama orang lain dalam solidaritas. Orang tidak dapat mencari menangnya sendiri, atau bahkan bersama dengan muridmuridnya. Karena itu, solidaritas menuntut adanya komunikasi sejati, dan

\footnotetext{
${ }^{16}$ Paulo Freire, Pendidikan Kaum Tertindas, h. 51.

${ }^{17}$ Paulo Freire, Pendidikan Kaum Tertindas, 53.

${ }^{18}$ Paulo Freire, Pendidikan Kaum Tertindas, 55.

${ }^{19}$ Paulo Freire, Pendidikan Kaum Tertindas, 54
} 
konsep gaya bank cenderung mengarahkan pendidik senangtiasa takut dan mejauhi komunikasi. ${ }^{20}$ Sementara itu, teori dan praktek pendidikan yang bergaya bank mengabdi kepada tujuan-tujuan tersebut dengan cara yaang sungguh efesien. Pelajaran-pelajaran yang verbalistik, bahan bacaan yang telah ditentukan, metode-metode untuk menilai ilmu pengetahuan, jarak antara murid dan guru, ukuran-ukuran bagi kenaikan kelas, segalah sesuatu dalam pendekatan siap pakai, hal ini melumpuhkan pikiran. Oleh karena itu, pendidikan gaya bank tidak bisa menharapkan teologi pembebasan kepada peserta didik. Sebaliknya, pendidikan pembebasan adalah musuh nyata yang akan merongrong dunia pendidikan, selama ini telah mapan dan membuat manusia tak berdaya atau dengan memakai ungkapan Suwito menjadi telmi.

Dengan demikian, konsep pengajaran model ala gaya bank sebagai problematika pembelajaran yang dilakukan pengajar sesungguhnya tidak pernah membelajarkan peserta didik. Pengajar diharapkan mampu mendesain pembelajaran yang dapat membelajarkan peserta didik, atau memimjam istilah Andrias Harefa menjadi manusia pembelajar, jika tidak kritik Paulo Freire terhadap dunia pendidikan yang disebut 'pendidikan gaya bank', masih sangat relevan sampai kini. Pendidikan 'gaya bank' memperlakukan masyarakat atau siswa sekolah sebagai obyek belajar (murid yang harus diajar atau dicekoki ilmu) dengan sifat ANTI DIALOGIS (searah) sehingga terjadilah proses dehumanisasi (penindasan). Hasil dari pendidikan semacam ini adalah 'burung beo' (murid yang pintar karena menghafal atau dimuati informasi sebanyak-banyaknya) tetapi canggung menghadapi realitas sosial atau kehidupan yang nyata. Jika tidak benahi, maka sangat wajar Seorang Ivan Illich dalam bukunya Descholing Society (1971) menghedaki sekolah-sekolah yang telah muncul dan berkembang dinegara-negara ketiga dibubarkan saja. Hal ini disebabkan karena sekolah-sekolah tidak mampu lagi membawa perubahan pada masyarakat, atau membelajarkan peserta didiknya, ${ }^{21}$ dan sekolah diharapkan sebagai sarana memanusiakan manusia, justru sebaliknya pendidikan tidak lagi membebaskan peserta didiknya. ${ }^{22}$

Oleh sebab itu, Hasil dari proses pembelajaran tersebut menurut Abduh hanya akan menghasilkan lulusan dan masyarakat yang jumud, membeku, statis, tidak ada perubahan. Oleh karena itu, pengajarannya lebih merupakan indoktrinasi tunggal tentang kebenaran yang tak mungkin dibantah. Ruang kelas bagaikan sebuah "penjara" tanpa peluang kreatif. Hal ini diakui oleh Mastuhu $^{23}$ bahwa para peserta didik tidak perlu menanyakan keabsahan dan kebenarannya serta tidak perlu mengajukan pertanyaan-pertanyaan yang

\footnotetext{
${ }^{20}$ Paulo Freire, Pendidikan Kaum Tertindas, 57

${ }^{21}$ Lihat Ainurrofiq Dawam, Emoh Sekolah,46

${ }^{22}$ Lihat Samsul Bahri, "Urgensi Pendidikan Akhlak bagi Peserta Didik" 96.

${ }^{23}$ Mastuhu, Memberdayakan Sistem Pendidikan Islam, 10.
} 
sifatnya elaborasi, provokatif, dan antisipatif dianggap tidak menghargai guru. Di ruang kelas, peserta didik hampir tak memiliki ruang eksperesi, sosok anak hanya akan berharga di mata guru jika sesuai dengan pendapat guru, pengelolah pendidikan, elit agama dan pemerintah selalu menggap makhluk yang tidak pernah salah atau istilah lain moralitas. Para siswa tidak pernah mengerti, mengalami, dan menyadari kebaikan dan kebenaran di saat paketpaket pembelajaran sudah tersedia. Tuhan pun tak pernah dikenal dan disadari, kecuali sifat-sifat hebat yang harus dihafalkan tanpa bertanya.

Lembaga sekolah disadari atau tidak secara sengaja menjerat generasi ke dalam lorong gelap peradaban. Di ujung lorong itu mungkin tersisa harapan, namun banyak yang tak acuh, dan menerima nasibnya sebagai takdir dari sang Ilahi. Hasil dari proses pembelajaran seperti inilah yang dimaksud Fazlur Rahman dengan memorizing, yakni proses pembelajaran yang memakai sistem hafalan daripada sistem pemahaman. Atau dengan kata lain menjadikan belajar berifat studi teks daripada pemahaman. ${ }^{24}$ Sinyelemen ini diperkuat oleh Tibi bahwa dunia pendidikan khusus universitas Arab dan Afrika dengan berbagai bidang studinya, berdasarkan semata-mata pada kapasitas belajar model hafalan (rote learning) dalam rangka mencapai lulusan. ${ }^{25}$

Model guru dalam konsep ini, guru pusat segalanya, maka merupakan hal yang lumrah saja jika murid-murid kemudian mengidentifikasi dirinya seperti guru yang harus diteladani dalam semua hal tanpa harus dikritisi. Atau dengan memakai tipologi Indra Djati Sidi, ${ }^{26}$ mengatakan guru adalah birokratbiroklat kecil. ${ }^{27}$ Inilah yang disebut Paulo Freire pendidikan yang menciptakan"nekrofili" dan bukan melahirkan "biofili". Implikasinya lahir generasi-generasi duflikasi dari guru, sehingga pada gilirangnya akan muncul manusia-manusia penindas. Jika diantara mereka ada yang menjadi pendidik maka tragedi penidasan segera dimulai dalam dunia pendidikan. ${ }^{28}$ Dengan demikian, konsep pendidikan gaya bank merupakan alat dari sebuah sistem penindasan ${ }^{29}$ bukan menjadi kekuatan pengugah (subversive force) kearah perubahan dan pembaharuan.

Dari pemahaman konsep pendidikan gaya bank peranan pendidik sangat ototriter, sehingga akan menghilangkan daya kritis dan kreativitas anak didik,

\footnotetext{
${ }^{24}$ Fazlur Rahman, Islam and Modernity, Transformation of an Intellectual Tradition, 189.

${ }^{25}$ Bassam Tibi, Iskam and the Cultural Accommodation of Social Change, 110.

${ }^{26}$ Indra Djati Sidi, adalah seorang praktisi pendidikan sekarang menjabat Direktur Jenderal Pendidikan Dasar dan Menengah (Dirjen Dikdasmen) Depdiknas RI (sejak 1998).

${ }^{27}$ Untuk lebih jelasnya baca Indra Djati Sidi, Menuju Masyarakat Belajar, Menggagas Paradigma Baru Pendidikan, 15

${ }^{28}$ Baca Paulo Freiere, The Politic of Education, Culture, and Leberation, xii.

${ }^{29}$ Baca Paulo Freiere, Pendidikan Kaum Tertindas, 56.
} 
serta menumbuhkan sikap pasif dan muda percaya yang tentu saja akan menguntungkan kaum penindas. Padahal sesungguhnya, kepentingan kaum penindas adalah "mengubah kesadaran kaum tertindas, bukan situasi yang menindas mereka". Sejalan dengan itu pula, dengan meminjam istilah Jean Paul Sarte sebagai pendidikan yang "menguyahkan" (disgestive) atau " memberi makan" ( Nutritive), di mana pengetahuan "disuapkan" oleh guru kepada murid untuk "mengeyangkan mereka". ${ }^{30}$

Konsep pendidikan di atas, telah menginkari dan menafitkan keberadaan anak didik sebagai seorang manusia yang memiliki potensi untuk berfikir. Bahkan konsep pendidikan tersebut sudah tidak netral lagi, melainkan sebagai sarana untuk "mereproduksi" sistem dan struktur sosial yan tidak adil. Karena itu, Pandangan Hinggins dan Roger sebagaimana dikutip Hasan Langgulung bahwa pendidikan harus menanamkan kembali pendidikan rohani (spritual) dan keimanan (faith) serta menempatkan pendidikan alinsaniah sebagai upaya membangkitkan kembali nilai-nilai fitra peserta didik yang potensial pada posisi yang ideal. ${ }^{31}$ Sebagai bukti bahwa pendidikan harus ditempatkan pada posisi humanisasi bukan dehumanisasi seperti konsep pendidikan gaya bank. Hal ini pun, diakui oleh Munir Muhkam bahwa gagasan utama pendidikan adalah bagaimana melahirkan manusia yang mempunyai daya kritis, kreatif dan keluhuran budi. ${ }^{32}$ Bahkan lebih lanjut mengatakan kebijakan pendidikan yang mengabaikan arti keunikan pribadi anak didik cenderung berakhir dengan kegagalan yang menimbulkan tragedi kemanusiaan. Karena itu, teori pendidikan dan pembelajaran hanya akan bermakna jika mampu memahami kepribadian sikap dan perasaan anak didik. $^{33}$ Oleh karenanya, kegagalan memahami kepribadian anak didik, terdapat dibanyak sekolah. Guru banyak tertarik pada usaha peningkatan kemampuan keterampilan dan memberi bimbingan yang mempermudah pertumbuhan emosional anak-anak. ${ }^{34}$ Namun jarang berhasil memahami perasaan dan pertumbuhan kepribadian peserta didik. Hal ini dipertegas kembali oleh Paulo Freire bahwa pola pendidikan seperti itu paling jauh hanya akan mampu merubah "penafsiran" seseorang terhadap situasi yang dihadapinya, namun tidak akan mampu merubah "realitas" dirinya sendiri. Manusia menjadi penonton dan peniru, bukan pencipta, sehingga muda dipahami mengapa suatu revolusi yang paling revolusioner sekalipun pada

\footnotetext{
${ }^{30}$ Baca Paulo Freiere, Pendidikan Kaum Tertindas, h. 56.

${ }^{31}$ Hinggins dan Roger, dalam Hasan Langgulung, Manusia dan Pendidikan, 200.

32 Munir Muhkam, Humanisasi pendidikan Islam, Tashwirul Afkar Jurnal Refleksi Pemikiran Keagamaan dan Kebudayaan,17-18.

${ }_{33}$ Munir Muhkam, Humanisasi pendidikan Islam, 25.

${ }^{34} \mathrm{M}$. Witmee and H. Conttingham, "The Teacher's Role and Guidance Functions as Reported by elementery Teacher," Elementary School Guidance and Counseling, 12-22.
} 
awal mulanya, tetapi digerakkan oleh orang-orang yang dihasilkan oleh sistem pendidikan mapan seperti itu, maka pada akhirnya hanyalah menggantikan simbol-simbol lama dengan simbol baru yang sebanarnya setali tiga uang yang sesungguhnya sama saja, terkadang jauh lebih buruk. ${ }^{35}$

Dengan demikian, pengajar harus mampu mencari paradigma yang membelajarkan peserta didik. Atau mamakai istilah Zamroni pendidikan untuk demokratisasi. ${ }^{36}$

\section{Pengajaran Hadap Masalah}

Membelajarkan sebagai kebalikan mengajar Guru bertugas untuk mengajar ( teaching), sedang murid bertugas menerima pelajaran (diajar). Metode yang digunakan disebut metode mengajar (pedagogi) yang sifatnya adalah komunikasi searah (dari guru ke murid) sehingga mengembangkan hubungan hirarkis. Begitu juga dengan penyuluh, meskipun bekerja dengan cara yang lebih partisipatif (penggunaan diskusi dan beragam media), namun intinya adalah sekedar transfer informasi 'dari luar' yang sering tidak relevan dengan realita masyarakat. Membelajarkan adalah mendorong peserta untuk belajar dan saling belajar, bukan mengajari. Fasilitator menggunakan metode pembelajaran orang dewasa (andragogi) yang sifatnya adalah komunikasi multiarah (dari peserta belajar ke peserta belajar, dari fasilitator ke peserta belajar, dan sebaliknya) sehingga mengembangkan proses dialog dan hubungan kesetaraan. Tema-tema belajarnya adalah keseharian, sehingga belajar menjadi relevan dengan kehidupan dan realitas peserta belajar.

Menurut Dede Rosyada dengan mengutip pendapat Hunt dan Moore dalam membelajarkan siswanya perlu memakai konsep reflective teaching bahwa guru harus merancang strategi sebelum dan dalam proses pembelajaran. Rancangan strategi sebelum proses pembelajaran harus memperhatikan pengalaman-pengalaman intraksi guru dengan siswa dalam pelajaran yang sama, kelas yang sama dan jam yang sama. Sedangkan rancangan dalam proses pembelajaran harus memperhatikan kondisi actual dan kenyataan riil dari siswa saat proses pembelajaran itu pembelajaran berjalan. ${ }^{37}$ Strategi ini harus disesuaikan dengan kebutuhan-kebutuhan siswa yang sangat dipengaruhi oleh tingkat penguasaan bahan ajar, emosi, citra diri dan harga diri yang selalu ingin dijunjung tinggi.

${ }^{35}$ Paulo Friere sangat mengecam kaum Marxis, disebabkan karena golongan yang paling getol mencap diri mereka sebagai kaum paling revolusioner, atau terhadap siapa saja yang mencap dirinya dan mengajurkan revolusi semata-mata sabagai alat perebutan kekuasaan hegemoni.

${ }^{36}$ Zamroni, Pendidikan Untuk Demokratisasi, 3.

${ }^{37}$ Dede Rosyada, Paradigma Pendidikan Demokratis, h. 97. 
Model pembelajaran tersebut merupakan salah satu model dari pembelajaran yang bisa mendinamisasikan siswa dalam proses belajar mengajar, atau dengan kata lain pembelajaran hadap masalah yang sering disebut Paulo Freire kegiatan pembelajaran sebagai proses AKSI REFLEKSIAKSI atau disebut juga sebagai proses DIALEKTIKA. Refleksi artinya merenungi, menganalisis, atau memaknai suatu peristiwa atau keadaan atau pengalaman, sehingga timbul kesadaran. Kesadaran itu, mendorong suatu tindakan atau aksi. Proses dialektika terjadi karenaperenungan itu menjadi pelajaran dan mendasari aksi berikutnya terutama untuk mengatasi dan mencari jalan keluar dari masalah yang terjadi. Karena itulah, konsep pembelajaran Paulo Freire juga disebut sebagai pendidikan HADAP MASALAH (problem posing). Kita belajar mengenai realitas kehidupan untuk bisa membuatnya lebih baik, itulah tujuan dari kita belajar. Proses pembelajaran aksi-refleksi-aksi terjadi berulang-ulang (bukan hanya satu kali) sehingga sebenarnya membentuk sebuah spiral pembelajaran. Setiap kali sebuah proses dialektika terjadi, akan dilanjutkan dengan dialektika berikutnya, dan begitu seterusnya. Artinya, sebuah proses pembelajaran tidak pernah menjadi rutinitas melainkan sebuah proses perkembangan dan transformasi. Belajar merupakan sesuatu yang terjadi sepanjang hidup.

Pada dasarnya pengajaran hadap masalah adalah suatu usaha untuk menjawab diskomunikasi antara guru dengan murid menuju suasana dialogis. Oleh karena itu, pelaksanaan pengajaran dapa masalah adalah adanya pemecahan masalah dalam proses belajar antara guru dengan murid. ${ }^{38}$ Mendinamisasikan peserta didik dalam proses pembelajaran dengan hubungan dialogis merupakan inti dari pengajaran hadap-masalah, sehingga guru tidak lagi menjadi orang yang mengajar, akan tetapi melakukan pembelajaran melalui dialog, dalam hal ini anak didik menjadi subjek yang belajar, yang bertindak dan berfikir dan pada saat bersamaan berbicara menyatakan hasil tindakan dan buah fikiran. Jadi keduanya (guru dan murid) ${ }^{39}$ saling belajar satu sama lain, saling memanusiakan. Dengan demikian, dalam proses ini guru mengajukan bahan untuk dipertimbangkan oleh murid dan pertimbangan sang guru sendiri kemudian diuji kembali setelah dipertemukan dengan pertimbangan murid-murid dan sebaliknya.

\footnotetext{
${ }^{38}$ Paulo Freire, Pendidikan Kaum Tertindas, 61
}

${ }^{39}$ Paulo Frire, menggunakan suatu istilah yang unik dan jelimet, yakni guru yang murid (teacher pupil) dan murid yang guru (pupil teacher), yang pada dasarnya sekedar menegaskan baik guru maupun murid memiliki potensi pengetahuan, penghayatan, dan pengalaman sendiri-sendiri terhadap obyek realitas yang mereka pelajari, sehingga bisa saja pada suatu saat murid menyajikan pengetahuan penghayatan, dan pengalaman tersebut sebagai insight bagi sang guru, seperti yang secara klasik menjadi tugas sang guru selama ini. 
Pengajaran hadap masalah adalah bagaimana usaha untuk membangun kreativitas peserta didik, hubungan dialogis serta mendorong sikap revolusioner untuk melangkah ke depan membangun masa depan peserta didik. Dengan kata lain, pengajaran hadap masalah sebenarnya mengisyaratkan bahwa dunia pendidikan seharusnya mampu membebaskan seluruh komponen pendidikan baik peserta didik, guru, kurikulum maupun lembaga pendidikannya. Hanya saja, pengajaran hadap masalah lebih memfokuskan bagaimana seorang guru membangun demokratisasi di dalam kelas, harus mampu menciptakan suasuana dialogis serta guru harus mampu menjadi seniman ${ }^{40}$ Adapun implementasi oprasional pengajaran hadap masalah ${ }^{41}$ lebih mengarah pada sistem pembelajaran, yaitu:

Pertama, dengan mengubah paradigma teaching (mengajar) menjadi learning (belajar). Di mana proses pendidikan yang dianut selama ini diubah dan menjadikan suasananya menjadi proses belajar bersama antara guru dan anak didik. Bukan hanya anak didik yang belajar namun posisi guru juga masih dalam proses belajar. Jadi anak didik tidak hanya didoktrin dengan materimateri pelajaran tetapi diberikan kebebasan untuk mengembangkan kreativitas dan potensi yang ia miliki.

Kedua, pendidikan harus bersifat learning to do (belajar berbuat/hidup). Aspek yang diingin dicapai dengan proses ini adalah siswa bisa mandiri dengan belajar mengatasi problem yang ia hadapi dalam kehidupan sehariharinya sebab pendidikan juga diarahkan pada cara mengatasai sendiri masalah yang ia hadapi. Ketiga, learning to live together (belajar hidup bersama) dan terakhir, learning to be, pendidikan merupakan tempat sarana belajar menjadi diri sendiri yang berkepribadian. Jadi intinya, paradigma pendidikan yang diinginkan adalah learning how to learn (belajar bagaimana belajar). Pendidikan tidak hanya berorientasi pada nilai akademik semata yang bersifat pemenuhan aspek kognitif saja tetapi juga berorientasi pada aspek afektif serta psikomotorik. Oleh karena itu, dalam era globaliasi ini pendidikan mampu melahirkan lulusan yang berorientasi masa depan, bersikap progresif, mampu memilah dan memilih secara bijak dan membuat perencanaan dengan baik.

Pengajaran hadap masalah seharusnya mampu menghasilkan anak didik yang memiliki keseimbangan antara penggunaan otak kiri dan otak kanan, ${ }^{42}$ manusia yang mempunyai kecerdesan intelektual, emosional, dan

${ }^{40}$ Paulo Freire, Menjadi Guru Yang Merdeka, 36-74

${ }^{41}$ Indra Djati Sidi, Menuju Masyarakat Belajar, 24-28.

42 Dalam psikologi kontemporer dikatakan bahwa otak kiri cenderung bekerja secara linear, matematis, kuantitatif, repetitif, dan parsial. Sedangkan otak kanan cenderung bekerja secara inovatif, kontemplatif, sintetik, holistik dan komprehensif. Komaruddin Hidayah, et.al., Agama di Tengah Kemelut, 93. 
spiritual. Dengan kata lain, Pendidikan juga memberikan keseimbangan antara pendidikan jasmani dan rohani, keseimbanngan antara pengetahuan alam dan pengetahuan sosial dan budaya serta keseimbangan antara pengetahuan masa kini dan pengetahuan masa lampau.

Dengan demikian dapat dirinci bahwa pengajaran hadap masalah harus mampu melahirkan peserta didik yang mempunyai ciri-ciri; 1) Terbuka dan bersedia menerima hal-hal baru hasil inovasi dan perubahan, (2) berorientasi demokratis dan mampu memiliki pendapat yang tidak selalu sama dengan pendapat orang lain, (3) berpijak pada kenyataan, menghargai waktu, konsisten dan sistematik dalam menyelesaikan masalah, (4) selalu terlibat dalam perencanaan dan pengorganisasian, (5) memiliki keyakinan bahwa segalanya dapat diperhitungkan, (6) menyadari dan menghargai pendapat orang lain, (7) rasional dan percaya pada kemampuan Iptek, (8) menjunjung tinggi keadilan berdasarkan prestasi, konstribusi, dan kebutuhan, (9) berorientasi pada produktivitas, efektivitas, dan efesien. ${ }^{43}$ Peserta didik yang memiliki ciri-ciri seperti itulah yang harus dihasilkan oleh dunia pendidikan yaitu manusia yang penuh kepercayaan diri (Self confident) serta mampu melakukan pilihan secara arif serta bersaing dalam era globalisasi yang kompetitif. ${ }^{44}$

Dengan demikian, model pengajaran hadap masalah merupakan model pengajaran yang harus dikembangkan oleh guru baik pada tingkat dasar maupun pada tingkat perguruan tinggi. Hal ini disebabkan model pengajaran hadap masalah adalah model pengajaran yang mampu mendinamisasikan dan membelajarkan peserta didik dalam proses belajar mengajar, sehingga tujuan pendidikan mamanusiakan manusia mampu tercapai dan pendidikan sebagai praktek pembebasan. Sebaliknya model pengajaran gaya bank yang mamatikan kreativitas, melumpuhkan pikiran, dan tidak membelajarkan peserta didik, saatnya untuk ditinggalkan, karena model seperti hanya akan melahirkan peserta didik jumud alias pembeo.

\section{Penutup}

Studi ini membuktikan bahwa pengajar yang membelajarkan adalah pengajar yang menggunakan model pengajaran hadap masalah, karena model ini mampu membangun kreativitas peserta dan demokratisasi dalam pembelajaran. Sebaliknya model pengajaran ala gaya bank justru mengebiri potensi kreativitas peserta didik yang membawa ke arah pengajaran feodalistik otoriter di mana peserta didik seperti tabula rasa, kertas putih

${ }^{43}$ Mastuhu, Memberdayakan Sistem Pendidikan Islam,47.

${ }^{44}$ Abuddin Nata, Pendidikan Islam di Indonesia; Tantangan dan Peluang, dalam pidato pengukuhan Guru Besar dalam Bidang Sejarah dan Filsafat Pendidikan Islam, 47. 
kosong yang harus di isi oleh guru. Namun demikian, fakta empiriknya pertarungan kedua model pengajaran tersebut di atas, masih sangat didominasi oleh model pengajaran ala gaya bank.

\section{Daftar Pustaka}

Al-Hamid Ghurab, Ahamad Abd, Abu Hasan al-Amiri wa Ara'uh alTarbawiyyah, dalam, Min A'lami al-Tarbiyah al-Tarbiyyah al-Arabiyyah al-Islamiyyah, Jilid II.

Bahri,Samsul, "Urgensi Pendidikan Akhlak bagi Peserta Didik" Jurnal Dinamika, Edisi: II/September, 2009.

Buchori, Muchtar, Ilmu Pendidikan dan Praktek Pendidikan, Jakarta, Muhammadiyah Press, 1994.

Dawam, Ainurrofiq, Emoh Sekolah, Yogyakarta, Inspeal Ahimsakarya Press, 2003.

Dede, Rosyada,, Paradigma Pendidikan Demokratis, Prenada, Jakarta, 2004.

Djati Sidi, Indra, Menuju Masyarakat Belajar, Menggagas Paradigma Baru Pendidikan, Jakarta, Paramadina dan Logos Wacana Ilmu, 2001.

Freire, Paulo, Menjadi Guru Yang Merdeka, Yogyakarta, LKiS, 2001, h. 36-74

--------, Pendidikan Kaum Tertindas, Jakarta, LP3ES, 2000.

-, The Politic of Education, Culture, and Leberation, New York, Begin and Garvey, 1985.

From,Eric, The Heart of Man, Routledge dan keegan, NY, 1966.

Hidayah, Komaruddin, et.al., Agama di Tengah Kemelut, Jakarta, Mediacita, 2001.

Hinggins dan Roger, dalam Hasan Langgulung, Manusia dan Pendidikan, Jakarta, Pustaka al-Husna 1989.

M. Witmee and H. Conttingham, "The Teacher's Role and Guidance Functions as Reported by elementery Teacher," Elementary School Guidance and Counseling, 1970.

Mastuhu, Memberdayakan Sistem Pendidikan Islam, Jakarta, Logos Wacana, 1999.

Muhkam, Munir, Humanisasi pendidikan Islam, Tashwirul Afkar Jurnal Refleksi Pemikiran Keagamaan dan Kebudayaan,Edisi No. 11, 2001.

Muska Mosston, Teaching from Command to Dicovery, Wasdsworth Publishing, Company, California, 1972.

Nata, Abuddin, Pendidikan Islam di Indonesia; Tantangan dan Peluang, dalam pidato pengukuhan Guru Besar dalam Bidang Sejarah dan Filsafat Pendidikan Islam, Jakarta, 20 Maret 2004. 2009.

Rahman, Fazlur, Islam and Modernity, Transformation of an Intellectual Tradition, Chicago, The Universty of Chicago Press, 1982.

Republika 10 April 2012.

Suparno, Paul, Guru Demokrasi di Era Reformasi, Grasindo, Jakarta, 2004. 
Suwito dalam upacara pengukuhan sebagai guru besar pada tanggal 3 Januari 2002 yang berjudul Pendidikan yang Memberdayakan.

Tibi, Bassam, Iskam and the Cultural Accommodation of Social Change, San Fransisco, Westview Press, 1985.

Zamroni, Pendidikan Untuk Demokratisasi, Bigraf, Yogyakarta, 2001 